\title{
Estimation of Evapotranspiration using CROPWAT 8.0 Model for Shipra River Basin in Madhya Pradesh, India
}

\author{
Ayushi Trivedi ${ }^{1 *}$, S.K. Pyasi ${ }^{1}$ and R.V. Galkate ${ }^{2}$ \\ ${ }^{1}$ Jawaharlal Nehru Krishi Vishwa Vidhalaya, Jabalpur, M.P., India \\ ${ }^{2}$ National Institute of Hydrology Regional Office Bhopaal, WALMI campus, India \\ *Corresponding author
}

\begin{tabular}{|c|}
\hline Keywords \\
\hline $\begin{array}{l}\text { Actual } \\
\text { evapotranspiration, } \\
\text { Potential } \\
\text { evapotranspiration, } \\
\text { Shipra river basin, } \\
\text { Evapotranspiration }\end{array}$ \\
\hline Article Info \\
\hline $\begin{array}{l}\text { Accepted: } \\
10 \text { April } 2018 \\
\text { Available Online: } \\
10 \text { May } 2018\end{array}$ \\
\hline
\end{tabular}

A B S T R A C T

Evapotranspiration is a key process of water balance and also an important element of energy balance. Its precise estimation is not only of vital importance for the study of climate change and evaluation of water resources, but also has much application value in crop water requirement management, drought forecasting and monitoring, effective water resources development and utilization etc. Actual evapotranspiration is a key process of hydrological cycle and a sole term that links land surface water balance and land surface energy balance. The study was conducted in Shipra river basin to determine actual evapotranspiration in the area. Long term daily meteorological data including rainfall, maximum temperature, minimum temperature, relative humidity, wind speed and sunshine hours of Indore IMD station was used as input data in CROPWAT Model 8.0. The potential evapotranspiration was converted into actual evapotranspiration by using the crop coefficient. Reference evapotranspiration is a measure of evaporative demand, while the crop coefficient accounts for crop characteristics and management practices (e.g., frequency of soil wetness).The major crop in the shipra river basin area are soyabean and sorghum which are kharif crop whereas the rabi crop in the area are wheat and gram and the summer or zaid crop in the area is sunflower. The value of $\mathrm{Kc}$ in, $\mathrm{Kc}$ mid, Kc end for the selected crop was obtained from department of irrigation. The maximum average actual ET was in the month of May i.e., $288 \mathrm{~mm}$ due to highest temperature in this month and the minimum average actual ET was in the month of November i.e., $34 \mathrm{~mm}$ due to minimum temperature in this month. Thus the experiment concluded that PET and AET increases as the temperature increases and it decreases as the temperature decreases.

\section{Introduction}

Land evapotranspiration process is invisible and difficult to measure, and needs to be determined by measurement and estimation (Lu et al., 2010). Actual evapotranspiration is a key process of hydrological cycle and a sole term that links land surface water balance and land surface energy balance. Evapotranspiration plays a key role in simulating hydrological effect of climate change. Evapotranspiration is a key process of water balance and also an important element of energy balance. Its precise estimation is not only of vital importance for the study of climate change and evaluation of water 
resources, but also has much application value in crop water requirement management, drought forecasting and monitoring, effective water resources development and utilization etc.

In arid regions, due to low rainfall conditions and high evaporation, agricultural development heavily depends on irrigation. Irrigation water accounts for over $80 \%$ of the total water consumption in such areas. Evapotranspiration (ET) is the transfer of water from the soil surface (evaporation) and plants (transpiration) to the atmosphere.

ET is a critical component of water balance at plot, field, farm, catchment, basin or global level. From an agricultural point of view, ET determines the amount of water to be applied through artificial means (irrigation). Reliable estimation of ET is important in that it determines the size of canals, pumps, and dams.

There are different methods for estimation of evapotranspiration. These are direct measurement methods and indirect methods which use weather data and soil water balance. These methods can be generally classified as empirical methods (eg. Thornthwaite, 1948; Blaney and Criddle, 1950) and physical based methods (e.g. Penman, 1948; Montheith, 1981 and FAO Penman Montheith (Allen et al., (1998)). They vary in terms of data requirement and accuracy. Some models are used to estimate ET such as the Two-Source Energy Balance Model or the CROPWAT model. Of these, the CROPWAT model is a reliable modelto calculate ET. This model has been provided by the United Nations Food and Agriculture Organization (FAO) and can directly output the ET and irrigation water requirements of crops. At present, the FAO Penman Montheith approach is considered as a standard method for ET estimation in agriculture (Allen et al., 1998).
There are two groups of evapotranspiration estimation methods in hydrological models: one first estimates separately water surface evaporation, soil evaporation and vegetable transpiration, and then integrates them to get the basin evapotranspiration depending on the land use pattern. The other one first estimates potential evapotranspiration (ET0) and then converts it into actual evapotranspiration (ETa) applying the Soil Moisture Extraction Function.

Vivekanand Singh et al., (2006) made an attempt to compare the reference evapotranspiration (REF-ET) computed using seven different methods namely PenmanMonteith, Priestley-Taylor, Turc, BlaneyCriddle, Hargreaves-Samani, Christiansen, and Pan evaporation for the Kashmir Valley. The Penman-Monteith method with grass as reference crop was chosen as the standard of comparison for evaluating the other six methods. Good correlation was found between the REF-ET values estimated by radiation and temperature based methods and the PenmanMonteith method. Dariush Rahimi et al., (2014) calculated real transpiration and evaporation of Brassica napus $L$ crop and water requirement and irrigation of this important crop in studied area using CROPWAT model. For this purpose, ecologic data average (maximum and minimum of temperature, monthly rainfall, wind speed, relative humidity and daily sunshine), crop cultivation pattern (implant date, coefficient amount of each stage of growth days, depth of root, depth of penetration), soil type, total accessible humidity, early humidity of the soil (in percentage from total humidity) and others are inserted in the model.

Hashem et al., (2016) developed a mathematical model to accurately calculate daily Reference Evapotranspiration (ETo) as a first step for the accurate calculation of irrigation water requirements. Also, the model 
output was compared to ETo estimated using CROPWAT, an irrigation software program used for ETo calculation and irrigation scheduling. The reference evapotranspiration model was built using the Food and Agricultural Organization FAO-56 PenmanMonteith equation with the SIMULINK tool in MATLAB software. The model was validated by comparing daily estimates of evapotranspiration with Class $\mathrm{A}$ pan and evapotranspiration gauges in the United States. The results indicated a good fit between daily ETo calculated by the model and that observed from Class A pan and evapotranspiration gauge.

In the current study CROPWAT 8.0 model is used to calculate the potential evapotranspiration using the input data and then using the crop coefficient for the reference crop actual evapotranspiration was calculated. Estimates of potential ET are used by professionals in the fields of hydrology, agriculture, and water management. Many irrigation companies use precipitation data and potential ET estimates to make irrigation recommendations for growers. Thus the current study conducted at Shipra basin can be used as a reference for calculating ET in other basins having the same climatic and physiological conditions.

\section{Materials and Methods}

Shipra is one of the sacred rivers in Hinduism. The holy city of Ujjain is situated on its right bank. After every 12 years, the KumbhMela (also called Simhastha) takes place at Ujjain on the city's elaborate riverside Ghats, besides yearly celebrations of the river goddess Kshipra. Shipra river basin has been extended between $76006^{\prime} 20^{\prime \prime}$ 'and $7505^{\prime} 60^{\prime}{ }^{\prime}$ ' North Latitude and $22097^{\prime} 00^{\prime \prime}$ 'and $23076^{\prime} 20^{\prime \prime}$ ' East Longitude and covers area of 5679 sq. km. The river traverses total course of about 190 $\mathrm{km}$. It originates from Kakribardi hills of Dhar and flows north across the Malwa Plateau to join the Chambal River. The average annual rainfall of area is about $931.87 \mathrm{~mm}$. The rainfall in the area is due to the southwest monsoon which starts from the middle of June and ends in last week of September. The topography is generally rolling to undulating. The hydrometric network in the basin consists six rain gauges and four meteorological stations maintained by the Indian Meteorological Department (IMD). The index map of Shipra river basin is given in Figure 1.

\section{Potential evapotranspiration estimation methods}

Potential evapotranspiration is an important input in hydrological cycle simulations. There are many kinds of potential evapotranspiration estimation methods however, the use of different methods to estimate potential evapotranspiration influences the simulation accuracy of a given hydrological model. Lindstrom (1997) analyzed the effect of different potential evapotranspiration calculation methods on the simulation accuracy of the HBV model. They found that the temperature-corrected Penman method improved the simulation accuracy nevertheless, with the Priestley-Taylor method the obtained results were better. Consequently, the best method was the Priestley-Taylor method, which improved the negative potential evapotranspiration in winter by considering the soil heat flux. The potential evapotranspiration estimation methods can be divided into the energy-based, temperaturebased and mass transfer-based methods, depending on their mechanisms. The energy based method applies the energy balance concept to estimate potential evapotranspiration. In $2000 \mathrm{Xu}$ and Singh compared 8 energy-based methods, including those described by Turc (1961), Makkink (1957), Jensen and Haise (1963), Hargreaves (1975), Doorenbos and Pruitt (1977), 
McGuinness and Bordne (1972), Abtew (1996) and Priestley and Taylor (1972). He found that: applying the Penman-Monteith method, Makkink, Priestley and Taylor and Abtew got better results than the other methods. Under limited climate data conditions many researchers proposed some temperature-based methods. In $2001 \mathrm{Xu}$ et al., analyzed seven types of temperature-based methods; the results show that the BlaneyCriddle method, the Hargreaves method and the Thornthwaite method give better simulation results than the other ones. The mass transfer-based method is one of the oldest one, which estimates free water surface potential evaporation and mainly considers the effect of air pressure deficit and wind speed (Singh et al., 1997). In 1802 Dalton proposed the first method of estimation of potential evaporation, while in 1948 Penman introduced his method based on the mass transfer principles. In the current study the CROPWAT Model is used to determine Potential evapotranspiration.

Hashem A (2016) developed a mathematical model to accurately calculate daily Reference Evapotranspiration (ETo) as a first step for the accurate calculation of irrigation water requirements. Also, the model output was compared to ETo estimated using CROPWAT, an irrigation software program used for ETo calculation and irrigation scheduling. The reference evapotranspiration model was built using the Food and Agricultural Organization FAO-56 PenmanMonteith equation with the SIMULINK tool in MATLAB software.

The model was validated by comparing daily estimates of evapotranspiration with Class A pan and evapotranspiration gauges in the United States. The results indicated a good fit between daily ETo calculated by the model and that observed from Class $\mathrm{A}$ pan and evapotranspiration gauge.
Tarate (2017) focused on estimating the reference evapotranspiration (ETo) using 32 years meteorological data by CROPWAT software. The FAO-56 Penman-Monteith method has been recommended as the standard method for estimating reference evapotranspiration (ET0) was used. The monthly average reference evapotranspiration was observed maximum in the month of May (8.4 mm day-1) while minimum in the month of December (3.27 mm day-1). This study provides the necessary information on water requirements for growing different crops in different season.

\section{CROPWAT 8.0 Model}

The CROPWAT model was developed by the Department of Land and Water Resources of FAO. CROPWAT 8.0 for Windows is a computer program for the calculation of crop water demand/requirements and irrigation demand/requirements based on soil, climate and crop data. In addition, the program allows the development of irrigation schedules for different management conditions and the calculation of scheme water supply for varying crop patterns. CROPWAT 8.0 can also be used to evaluate farmers irrigation practices and to estimate crop performance under both rainfed and irrigated conditions.

The development of irrigation schedules in CROPWAT 8.0 is based on a daily soil-water balance using various user-defined options for water supply and irrigation management conditions.

Its basic functions include:

Calculating the reference ET (ET0).

Calculating the ET of the crop.

Calculating the irrigation water requirement of the crop. 
Formulating and evaluating the irrigation regime.

\section{Data required in estimation of potential evapotranspiration}

The input data used for calculating the potential evapotranspiration are listed below-

Minimum temperature $\left({ }^{\circ} \mathrm{C}\right)$

Maximum temperature $\left({ }^{\circ} \mathrm{C}\right)$

Sunshine hours (hrs)

Wind speed ( $\mathrm{km} /$ day)

Relative humidity (\%)

Latitude

Longitude

Altitude

The output given by cropwat model is-

Radiation $\left(\mathrm{MJ} / \mathrm{m}^{2} /\right.$ day $)$

$\mathrm{ET}_{0}$ potential evapotranspiration ( $\mathrm{mm} /$ day)

Calculation of potential evapotranspiration of the Shipra river basin was important due to its high effect on runoff in the form of evaporation from the surface. More evaporation causes the additional loss of water from the basin which was the part of runoff. The evapotranspiration is very low in autumn and winter and its influence on runoff is almost negligible. In the current study, Penman-Monteith formula is used for calculating the evapotranspiration because it require the minimum temperature $\left({ }^{\circ} \mathrm{C}\right)$, maximum temperature $\left({ }^{\circ} \mathrm{C}\right)$, sunshine hours, wind speed and relative humidity as input which was available for the study area that is shipra river basin provided by IMD. The evapotranspiration is one of the most important components of RRL AWBM model which has to be use in the study therefore evapotranspiration is estimated using CROPWAT 8.0 model. Penman-Monteith equation used in the study is expressed mathematically in equation (1).

$$
\mathrm{ET}_{0}=\frac{0.408 \Delta\left(\mathrm{R}_{\mathrm{n}}-\mathrm{G}\right)+\mathrm{\gamma} \frac{900}{\mathrm{~T}+273}\left(\mathrm{e}_{\mathrm{s}}-\mathrm{e}_{\mathrm{a}}\right)}{\Delta+\mathrm{Y}\left(1+0.34 \mathrm{u}_{2}\right)}
$$

Where,

$\mathrm{ET}^{0}=$ Reference evapotranspiration $(\mathrm{mm} /$ day)

$\mathrm{R}_{\mathrm{n}}=$ Net radiation at the crop surface $\left(\mathrm{MJ} \mathrm{m}^{2}\right.$

/day)

$\mathrm{G}=$ Soil heat flux density $\left(\mathrm{MJ} \mathrm{m}^{2} /\right.$ day $)$

$\mathrm{T}=$ Mean daily air temperature at $2 \mathrm{~m}$ height

$\left({ }^{\circ} \mathrm{C}\right)$

$\mathrm{u}_{2}=$ Wind speed at $2 \mathrm{~m}$ height $(\mathrm{m} / \mathrm{s})$

$\mathrm{e}_{\mathrm{s}}=$ Saturation vapour pressure $(\mathrm{kpa})$

$\mathrm{e}_{\mathrm{a}}=$ Actual vapour pressure $(\mathrm{kpa})$

$\mathrm{e}_{\mathrm{s}}-\mathrm{e}_{\mathrm{a}}=$ Saturation vapour pressure deficit (kpa)

${ }^{\Delta}$ = Slope vapour pressure curve $\left(\mathrm{kpa} /{ }^{\circ} \mathrm{C}\right)$

$\Gamma^{\Gamma}=$ Psychrometric constant $\left(\mathrm{kpa} /{ }^{\circ} \mathrm{C}\right)$

The potential evapotranspiration was converted into actual evapotranspiration by using the crop coefficient. Reference evapotranspiration is a measure of evaporative demand, while the crop coefficient accounts for crop characteristics and management practices (e.g., frequency of soil wetness). India is top producer country of many crops. The major crops in India can be divided into four categories viz. Food grains (Rice, Wheat, Maize, Millets and Pulses), Cash Crops (Cotton, Jute, Sugarcane, Tobacco, and Oilseeds), Plantation Crops (Tea, Coffee, Coconut and, Rubber) and Horticulture crops such as Fruits and Vegetables. On the basis of seasons, the crops in India have been divided into Rabi, Kharif and Zaid crops. The Kharif crop is the summer crop or monsoon crop in India. Kharif crops are usually sown with the beginning of the first rains in July, during the south-west monsoon season. Major Kharif crops of India include Millets (Bajra\&Jowar), 
Cotton, Soyabean, Sugarcane, Turmeric, Paddy (Rice), Maize, Moong (Pulses), Groundnut, Red Chillies, etc. The Rabi crop is the spring harvest or winter crop in India. It is sown in October last and harvested in March April every year. Major Rabi crops in India include Wheat, Barley, Mustard, Sesame, Peas etc. The zaid crop is grown in some parts of country during March to June. Prominent examples are Muskmelon, Watermelon, Vegetables of cucurbitacae family such as bitter gourd, pumpkin, ridged gourd etc. The major crop in the shipra river basin area are soyabean and sorghum which are kharif crop whereas the rabi crop in the area are wheat and gram and the summer and zaid crop in the area is sunflower. The CROPWAT model uses the single crop coefficient method to calculate ET via the following formula:

$E T=K c * E T 0$

Where,

$\mathrm{Kc}$ is the crop coefficient

ET is the actual evapotranspiration

ETO is the potential evapotranspiration

The internationally recognized crop growth stages for the calculation of crop coefficients are initial, development, mid-season and late season stages (Allen et al., 1998). The FAO and WMO (World Meteorological Organization) experts have summarised such evolution in the "crop coefficient curve" to identify the Kc value corresponding to the different crop development and growth stages (initial, middle and late, hence it has $\mathrm{Kc}$ in, $\mathrm{Kc}$ mid, Kc end) (Tarantino and Spano, 2001). Values of $\mathrm{Kc}$ for most agricultural crops increase from a minimum value at planting until maximum $\mathrm{Kc}$ is reached at about full canopy cover. The Crop coefficients (Kc) values during the growing stages of different crops are in Table 1. The Kc tends to decline at a point after a full cover is reached in the crop season. The value of $\mathrm{Kc}$ in, Kc mid, Kc end for the selected crop is represented in the Table 2 which was obtained from department of irrigation.

The average crop coefficient calculated for each month is represented in the Table 3 was determined using weighted average method.

\section{Results and Discussion}

In this study the potential evapotranspiration was determined using CROPWAT 8.0 Model and subsequently actual evapotranspiration was obtained using crop coefficient multiplied by potential evapotranspiration for the Shipra river basin. The CROPWAT 8.0 Model requires the time series data of minimum temperature, maximum temperature, latitude, longitude, altitude, sunshine hours and wind velocity. The data starting from 1990 to 2010 was collected and analysed for the selected districts that is Ujjain, Indore, Ratlam, Dewas and Sanwer which lies in the Shipra basin. The daily potential evapotranspiration (mm/day) obtained by CROPWAT 8.0 model is given below in Table 4 .

From the Table 5 and Figure 2 it can clearly be depicted that maximum monthly ETo was estimated $343.8 \mathrm{~mm}$ in the month of May for the average period considered for the study and also for each years, the average highest annual ETo value is $2077.9 \mathrm{~mm}$ due to high temperature during the year 1991 .

Whereas minimum monthly ETo is estimated as $59.8 \mathrm{~mm}$ in the month of January due to winter months and low temperature. The average lowest annual ETo value is $1513 \mathrm{~mm}$ in the year 2001.Thus it can easily be concluded that as the temperature increases the ETo increases and as the temperature decreases the ETo decreases. 
Table.1 Crop coefficients $(\mathrm{Kc})$ values during the growing stages of different crops

\begin{tabular}{|c|c|c|c|c|c|c|}
\hline \multirow{2}{*}{$\begin{array}{c}\text { S. } \\
\text { no }\end{array}$} & Crop & \multicolumn{5}{|c|}{ Kc values during different crop development stages } \\
\cline { 3 - 7 } & & Initial & $\begin{array}{c}\text { Crop } \\
\text { development }\end{array}$ & Mid season & Late season & At harvest \\
\hline 1 & Paddy & $1.10-1.15$ & $1.10-1.50$ & $1.10-1.30$ & $0.95-1.05$ & $0.95-1.05$ \\
\hline 2 & Soyabean & $0.30-0.40$ & $0.70-0.80$ & $1.00-1.15$ & $0.70-0.80$ & $0.40-0.50$ \\
\hline 3 & Sorghum & $0.30-0.40$ & $0.70-0.75$ & $1.00-1.15$ & $0.75-0.80$ & $0.50-0.55$ \\
\hline 4 & Cotton & $0.40-0.50$ & $0.70-0.80$ & $1.05-1.25$ & $0.80-0.90$ & $0.65-0.70$ \\
\hline 5 & Maize & $0.40-0.50$ & $0.70-0.90$ & $1.05-1.20$ & $1.00-1.15$ & $0.95-1.10$ \\
\hline 6 & Pearl-millet & $0.25-0.30$ & $0.40-0.70$ & $1.05-1.10$ & $1.00-1.05$ & $0.40-0.70$ \\
\hline 7 & Black gram & $0.25-0.30$ & $0.40-0.70$ & $1.00-1.10$ & $1.00-1.10$ & $0.50-0.80$ \\
\hline 8 & Vegetable & $0.25-0.40$ & $0.50-0.60$ & $0.60-0.70$ & $0.50-0.70$ & $0.50-0.70$ \\
\hline 9 & Seasamum & $0.25-0.30$ & $0.40-0.60$ & $0.90-1.15$ & $0.80-1.10$ & $0.70-0.90$ \\
\hline 10 & Groundnut & $0.30-0.40$ & $0.40-0.80$ & $0.80-1.00$ & $0.80-0.90$ & $0.70-0.80$ \\
\hline 11 & Sugarcane & $0.50-0.60$ & $0.60-0.90$ & $1.00-1.15$ & $1.10-1.20$ & $1.00-1.20$ \\
\hline
\end{tabular}

Table.2 Value of Kc in, Kc mid, Kc end for the selected crop

\begin{tabular}{|c|c|c|c|}
\hline Crop & Kc in & Kc mid & Kc end \\
\hline Soyabean & 0.40 & 1.15 & $\mathbf{0 . 5 0}$ \\
\hline Sorghum & 0.30 & 1.05 & $\mathbf{0 . 5 5}$ \\
\hline Wheat & 0.30 & 1.15 & $\mathbf{0 . 2 5}$ \\
\hline Gram & 0.40 & 1.00 & $\mathbf{0 . 3 5}$ \\
\hline Sunflower & $\mathbf{0 . 5 2}$ & $\mathbf{1 . 1 1}$ & $\mathbf{0 . 4 1}$ \\
\hline
\end{tabular}

Table.3 Average crop coefficient for each month

\begin{tabular}{|l|l|}
\hline Year & Avgkc \\
\hline Jan & 1.075 \\
\hline Feb & 0.3 \\
\hline Mar & 0.52 \\
\hline Apr & 1.11 \\
\hline May & 1.11 \\
\hline Jun & 0.41 \\
\hline Jul & 0.35 \\
\hline Aug & 1.1 \\
\hline Sep & 1.1 \\
\hline Oct & 0.525 \\
\hline Nov & 0.35 \\
\hline Dec & 1.075 \\
\hline
\end{tabular}


Table.4 Estimated daily potential evapotranspiration (mm/day) for the year 1990 to 2010

\begin{tabular}{|l|l|l|l|l|l|l|l|l|l|l|l|l|}
\hline Year & Jan & Feb & Mar & Apr & May & June & July & Aug & Sept & Oct & Nov & Dec \\
\hline $\mathbf{1 9 9 0}$ & 3.71 & 4.72 & 7.01 & 7.31 & 5.88 & 6.93 & 5.91 & 5.87 & 6.09 & 4.46 & 3.39 & 3.4 \\
\hline $\mathbf{1 9 9 1}$ & 3.43 & 4.84 & 6.7 & 7.13 & 6.92 & 7.85 & 6.75 & 6.79 & 6.72 & 4.71 & 3.19 & 3.27 \\
\hline $\mathbf{1 9 9 2}$ & 3.78 & 4.71 & 6.78 & 6.7 & 6.56 & 9.37 & 8.11 & 5.94 & 2.81 & 4.72 & 3.29 & 3.21 \\
\hline $\mathbf{1 9 9 3}$ & 3.55 & 4.71 & 6.73 & 7.19 & 6.72 & 8.55 & 6.58 & 6.84 & 6.42 & 4.36 & 3.26 & 3.05 \\
\hline $\mathbf{1 9 9 4}$ & 3.38 & 4.4 & 6.16 & 6.88 & 7.28 & 6.95 & 4.91 & 5.56 & 5.78 & 4.27 & 3.19 & 2.97 \\
\hline $\mathbf{1 9 9 5}$ & 3.02 & 4.44 & 5.65 & 6.24 & 6.27 & 8.18 & 6.3 & 6.77 & 6.34 & 4.77 & 3.32 & 3.67 \\
\hline $\mathbf{1 9 9 6}$ & 3.42 & 4.81 & 6.47 & 8.13 & 10.01 & 8.77 & 4.49 & 3.53 & 4.27 & 4.27 & 3.7 & 3.2 \\
\hline $\mathbf{1 9 9 7}$ & 3.23 & 4.64 & 5.99 & 7.61 & 9.64 & 6.58 & 3.86 & 3.57 & 4.02 & 4.29 & 3.38 & 2.34 \\
\hline $\mathbf{1 9 9 8}$ & 3.02 & 4.32 & 5.99 & 8.19 & 9.65 & 7.48 & 4.04 & 3.57 & 3.77 & 4.42 & 3.52 & 3.09 \\
\hline $\mathbf{1 9 9 9}$ & 3.35 & 3.88 & 6.37 & 8.31 & 9.73 & 6.47 & 4.07 & 3.76 & 3.5 & 3.91 & 3.71 & 2.99 \\
\hline $\mathbf{2 0 0 0}$ & 3.62 & 4.35 & 6.57 & 8.93 & 7.97 & 6.93 & 3.56 & 4.19 & 4.17 & 3.06 & 3.08 & 2.52 \\
\hline $\mathbf{2 0 0 1}$ & 2.85 & 4.17 & 5.62 & 6.05 & 8.2 & 5.31 & 3.03 & 2.99 & 3.64 & 3.26 & 2.46 & 2.18 \\
\hline $\mathbf{2 0 0 2}$ & 3.36 & 4.33 & 5.52 & 7.53 & 9.38 & 6.12 & 5.5 & 2.75 & 4.17 & 4.42 & 3.43 & 3.29 \\
\hline $\mathbf{2 0 0 3}$ & 3.38 & 4.31 & 5.71 & 7.44 & 9.25 & 6.46 & 3.94 & 3.13 & 3 & 4.23 & 3.31 & 2.99 \\
\hline $\mathbf{2 0 0 4}$ & 3.12 & 4.04 & 5.38 & 8.49 & 9.35 & 7.4 & 4.41 & 2.91 & 4.25 & 3.59 & 3.16 & 2.81 \\
\hline $\mathbf{2 0 0 5}$ & 3.06 & 4.35 & 5.92 & 7.24 & 8.85 & 7.72 & 4.23 & 3.69 & 3.63 & 4.24 & 3.35 & 2.81 \\
\hline $\mathbf{2 0 0 6}$ & 3.15 & 4.3 & 5.2 & 7.4 & 9.01 & 7.13 & 3.95 & 3.35 & 3.63 & 4.1 & 3.25 & 3 \\
\hline $\mathbf{2 0 0 7}$ & 3.53 & 4.97 & 6.74 & 8.54 & 11.09 & 7.4 & 4.53 & 3.3 & 4.21 & 4.37 & 3.49 & 2.74 \\
\hline $\mathbf{2 0 0 8}$ & 3 & 4.15 & 5.61 & 6.74 & 9.25 & 7.23 & 4.13 & 3.38 & 3.07 & 3.62 & 3.79 & 3.59 \\
\hline $\mathbf{2 0 0 9}$ & 3.29 & 3.77 & 5.85 & 6.98 & 8.74 & 7.39 & 4.85 & 3.11 & 3.11 & 3.08 & 2.41 & 1.94 \\
\hline $\mathbf{2 0 1 0}$ & 1.93 & 2.74 & 3.22 & 5.3 & 6.2 & 6.33 & 4.49 & 3.38 & 2.73 & 3.24 & 2.93 & 2.24 \\
\hline & & & & & & & & & & & \\
\hline
\end{tabular}

Table.5 Monthly potential evapotranspiration for the year 1990 to 2010

\begin{tabular}{|c|c|c|c|c|c|c|c|c|c|c|c|c|c|}
\hline Year & Jan & Feb & Mar & Apr & May & June & July & Aug & Sept & Oct & Nov & Dec & Annual \\
\hline 1990 & 115.0 & 132.2 & 217.3 & 219.3 & 182.3 & 207.9 & 183.2 & 182.0 & 182.7 & 138.3 & 101.7 & 105.4 & 1967.2 \\
\hline 1991 & 106.3 & 135.5 & 207.7 & 213.9 & 214.5 & 235.5 & 209.3 & 210.5 & 201.6 & 146.0 & 95.7 & 101.4 & 2077.9 \\
\hline 1992 & 117.2 & 131.9 & 210.2 & 201.0 & 203.4 & 281.1 & 251.4 & 184.1 & 84.3 & 146.3 & 98.7 & 99.5 & 2009.1 \\
\hline 1993 & 110.1 & 131.9 & 208.6 & 215.7 & 208.3 & 256.5 & 204.0 & 212.0 & 192.6 & 135.2 & 97.8 & 94.6 & 2067.2 \\
\hline 1994 & 104.8 & 123.2 & 191.0 & 206.4 & 225.7 & 208.5 & 152.2 & 172.4 & 173.4 & 132.4 & 95.7 & 92.1 & 1877.6 \\
\hline 1995 & 93.6 & 124.3 & 175.2 & 187.2 & 194.4 & 245.4 & 195.3 & 209.9 & 190.2 & 147.9 & 99.6 & 113.8 & 1976.7 \\
\hline 1996 & 106.0 & 134.7 & 200.6 & 243.9 & 310.3 & 263.1 & 139.2 & 109.4 & 128.1 & 132.4 & 111.0 & 99.2 & 1977.9 \\
\hline 1997 & 100.1 & 129.9 & 185.7 & 228.3 & 298.8 & 197.4 & 119.7 & 110.7 & 120.6 & 133.0 & 101.4 & 72.5 & 1798.1 \\
\hline 1998 & 93.6 & 121.0 & 185.7 & 245.7 & 299.2 & 224.4 & 125.2 & 110.7 & 113.1 & 137.0 & 105.6 & 95.8 & 1856.9 \\
\hline 1999 & 103.9 & 108.6 & 197.5 & 249.3 & 301.6 & 194.1 & 126.2 & 116.6 & 105.0 & 121.2 & 111.3 & 92.7 & 1827.9 \\
\hline 2000 & 112.2 & 121.8 & 203.7 & 267.9 & 247.1 & 207.9 & 110.4 & 129.9 & 125.1 & 94.9 & 92.4 & 78.1 & 1791.3 \\
\hline 2001 & 88.4 & 116.8 & 174.2 & 181.5 & 254.2 & 159.3 & 93.9 & 92.7 & 109.2 & 101.1 & 73.8 & 67.6 & 1512.6 \\
\hline 2002 & 104.2 & 121.2 & 171.1 & 225.9 & 290.8 & 183.6 & 170.5 & 85.3 & 125.1 & 137.0 & 102.9 & 102.0 & 1819.6 \\
\hline 2003 & 104.8 & 120.7 & 177.0 & 223.2 & 286.8 & 193.8 & 122.1 & 97.0 & 90.0 & 131.1 & 99.3 & 92.7 & 1738.5 \\
\hline 2004 & 96.7 & 113.1 & 166.8 & 254.7 & 289.9 & 222.0 & 136.7 & 90.2 & 127.5 & 111.3 & 94.8 & 87.1 & 1790.8 \\
\hline 2005 & 94.9 & 121.8 & 183.5 & 217.2 & 274.4 & 231.6 & 131.1 & 114.4 & 108.9 & 131.4 & 100.5 & 87.1 & 1796.8 \\
\hline 2006 & 97.7 & 120.4 & 161.2 & 222.0 & 279.3 & 213.9 & 122.5 & 103.9 & 108.9 & 127.1 & 97.5 & 93.0 & 1747.3 \\
\hline 2007 & 109.4 & 139.2 & 208.9 & 256.2 & 343.8 & 222.0 & 140.4 & 102.3 & 126.3 & 135.5 & 104.7 & 84.9 & 1973.7 \\
\hline 2008 & 93.0 & 116.2 & 173.9 & 202.2 & 286.8 & 216.9 & 128.0 & 104.8 & 92.1 & 112.2 & 113.7 & 111.3 & 1751.1 \\
\hline 2009 & 102.0 & 105.6 & 181.4 & 209.4 & 270.9 & 221.7 & 150.4 & 96.4 & 93.3 & 95.5 & 72.3 & 60.1 & 1658.9 \\
\hline 2010 & 59.8 & 76.7 & 99.8 & 159.0 & 192.2 & 189.9 & 139.2 & 104.8 & 81.9 & 100.4 & 87.9 & 69.4 & 1361.1 \\
\hline AVG & 100.6 & 121.3 & 184.8 & 220.5 & 259.7 & 217.9 & 150.0 & 130.5 & 127.6 & 126.1 & 98.0 & 90.5 & 1827.5 \\
\hline
\end{tabular}


Int.J.Curr.Microbiol.App.Sci (2018) 7(5): 1248-1259

Table.6 Daily estimated actual evapotranspiration for the year 1990 to 2010

\begin{tabular}{|c|c|c|c|c|c|c|c|c|c|c|c|c|}
\hline Year & Jan & Feb & Mar & Apr & May & Jun & Jul & Aug & Sep & Oct & Nov & Dec \\
\hline 1990 & 3.99 & 1.42 & 3.65 & 8.11 & 6.52 & 2.84 & 2.06 & 6.45 & 6.69 & 2.34 & 1.18 & 3.65 \\
\hline 1991 & 3.69 & 1.45 & 3.48 & 7.91 & 7.68 & 3.21 & 2.36 & 7.46 & 7.39 & 2.47 & 1.11 & 3.51 \\
\hline 1992 & 4.06 & 1.41 & 3.53 & 7.43 & 7.28 & 3.84 & 2.83 & 6.53 & 3.09 & 2.47 & 1.15 & 3.40 \\
\hline 1993 & 3.82 & 1.41 & 3.50 & 7.98 & 7.45 & 3.50 & 2.30 & 7.52 & 7.06 & 2.28 & 1.14 & 3.27 \\
\hline 1994 & 3.63 & 1.32 & 3.20 & 7.63 & 8.08 & 2.84 & 1.71 & 6.11 & 6.35 & 2.24 & 1.11 & 3.19 \\
\hline 1995 & 3.25 & 1.33 & 2.94 & 6.92 & 6.95 & 3.35 & 2.22 & 7.44 & 6.97 & 2.50 & 1.16 & 3.94 \\
\hline 1996 & 3.67 & 1.44 & 3.36 & 9.02 & 11.11 & 3.60 & 1.57 & 3.88 & 4.70 & 2.24 & 1.30 & 3.44 \\
\hline 1997 & 3.47 & 1.39 & 3.11 & 8.45 & 10.70 & 2.70 & 1.35 & 3.93 & 4.42 & 2.25 & 1.18 & 2.52 \\
\hline 1998 & 3.25 & 1.30 & 3.11 & 9.09 & 10.71 & 3.07 & 1.41 & 3.93 & 4.15 & 2.32 & 1.23 & 3.32 \\
\hline 1999 & 3.60 & 1.16 & 3.31 & 9.22 & 10.80 & 2.65 & 1.42 & 4.14 & 3.85 & 2.05 & 1.30 & 3.21 \\
\hline 2000 & 3.89 & 1.31 & 3.42 & 9.91 & 8.85 & 2.84 & 1.25 & 4.61 & 4.59 & 1.61 & 1.08 & 2.71 \\
\hline 2001 & 3.06 & 1.25 & 2.92 & 6.72 & 9.10 & 2.18 & 1.06 & 3.29 & 4.00 & 1.71 & 0.86 & 2.34 \\
\hline 2002 & 3.61 & 1.30 & 2.87 & 8.36 & 10.41 & 2.51 & 1.93 & 3.03 & 4.59 & 2.32 & 1.20 & 3.53 \\
\hline 2003 & 3.63 & 1.29 & 2.97 & 8.26 & 10.27 & 2.65 & 1.38 & 3.44 & 3.30 & 2.22 & 1.16 & 3.21 \\
\hline 2004 & 3.35 & 1.21 & 2.80 & 9.42 & 10.38 & 3.03 & 1.54 & 3.20 & 4.68 & 1.88 & 1.11 & 3.02 \\
\hline 2005 & 3.29 & 1.31 & 3.08 & 8.04 & 9.82 & 3.17 & 1.48 & 4.06 & 3.99 & 2.23 & 1.17 & 3.02 \\
\hline 2006 & 3.39 & 1.29 & 2.70 & 8.21 & 10.00 & 2.92 & 1.38 & 3.69 & 3.99 & 2.15 & 1.14 & 3.23 \\
\hline 2007 & 3.60 & 1.49 & 3.50 & 9.47 & 12.30 & 3.03 & 1.58 & 3.63 & 4.63 & 2.29 & 1.22 & 2.94 \\
\hline 2008 & 3.23 & 1.24 & 2.92 & 7.48 & 10.26 & 2.96 & 1.44 & 3.71 & 3.37 & 1.90 & 1.32 & 3.85 \\
\hline 2009 & 3.54 & 1.13 & 3.04 & 7.74 & 9.70 & 3.02 & 1.69 & 3.42 & 3.42 & 1.61 & 0.84 & 2.08 \\
\hline 2010 & 2.07 & 0.88 & 1.67 & 5.58 & 6.88 & 2.59 & 1.57 & 3.71 & 3.00 & 1.70 & 1.03 & 2.40 \\
\hline
\end{tabular}

Table.7 Estimated monthly and annual actual evapotranspiration for the year 1990 to 2010

\begin{tabular}{|c|c|c|c|c|c|c|c|c|c|c|c|c|c|}
\hline Year & Jan & Feb & Mar & Apr & May & Jun & Jul & Aug & Sep & Oct & Nov & Dec & Annual \\
\hline $\mathbf{1 9 9 0}$ & 124 & 40 & 113 & 243 & 202 & 85 & 64 & 200 & 201 & 73 & 35 & 113 & 1493 \\
\hline $\mathbf{1 9 9 1}$ & 114 & 41 & 108 & 237 & 238 & 96 & 73 & 231 & 222 & 77 & 33 & 109 & 1580 \\
\hline $\mathbf{1 9 9 2}$ & 126 & 40 & 109 & 223 & 226 & 115 & 88 & 202 & 93 & 77 & 35 & 105 & 1438 \\
\hline $\mathbf{1 9 9 3}$ & 118 & 40 & 108 & 239 & 231 & 105 & 71 & 233 & 212 & 71 & 34 & 101 & 1564 \\
\hline $\mathbf{1 9 9 4}$ & 113 & 37 & 99 & 229 & 250 & 85 & 53 & 189 & 191 & 69 & 33 & 99 & 1448 \\
\hline $\mathbf{1 9 9 5}$ & 101 & 37 & 91 & 208 & 215 & 101 & 69 & 231 & 209 & 78 & 35 & 122 & 1496 \\
\hline $\mathbf{1 9 9 6}$ & 114 & 40 & 104 & 271 & 344 & 108 & 49 & 120 & 141 & 69 & 39 & 107 & 1506 \\
\hline $\mathbf{1 9 9 7}$ & 108 & 39 & 97 & 253 & 332 & 81 & 42 & 122 & 133 & 70 & 35 & 78 & 1389 \\
\hline $\mathbf{1 9 9 8}$ & 101 & 36 & 97 & 273 & 332 & 92 & 44 & 122 & 124 & 72 & 37 & 103 & 1432 \\
\hline $\mathbf{1 9 9 9}$ & 112 & 33 & 103 & 277 & 335 & 80 & 44 & 128 & 116 & 64 & 39 & 100 & 1428 \\
\hline $\mathbf{2 0 0 0}$ & 121 & 37 & 106 & 297 & 274 & 85 & 39 & 143 & 138 & 50 & 32 & 84 & 1405 \\
\hline $\mathbf{2 0 0 1}$ & 95 & 35 & 91 & 201 & 282 & 65 & 33 & 102 & 120 & 53 & 26 & 73 & 1176 \\
\hline $\mathbf{2 0 0 2}$ & 112 & 36 & 89 & 251 & 323 & 75 & 60 & 94 & 138 & 72 & 36 & 109 & 1395 \\
\hline $\mathbf{2 0 0 3}$ & 113 & 36 & 92 & 248 & 318 & 79 & 43 & 107 & 99 & 69 & 35 & 100 & 1338 \\
\hline $\mathbf{2 0 0 4}$ & 104 & 34 & 87 & 283 & 322 & 91 & 48 & 99 & 140 & 58 & 33 & 94 & 1393 \\
\hline $\mathbf{2 0 0 5}$ & 102 & 37 & 95 & 241 & 305 & 95 & 46 & 126 & 120 & 69 & 35 & 94 & 1364 \\
\hline $\mathbf{2 0 0 6}$ & 105 & 36 & 84 & 246 & 310 & 88 & 43 & 114 & 120 & 67 & 34 & 100 & 1347 \\
\hline $\mathbf{2 0 0 7}$ & 112 & 42 & 109 & 284 & 381 & 91 & 49 & 113 & 139 & 71 & 37 & 91 & 1517 \\
\hline $\mathbf{2 0 0 8}$ & 100 & 35 & 90 & 224 & 318 & 89 & 45 & 115 & 101 & 59 & 40 & 119 & 1335 \\
\hline $\mathbf{2 0 0 9}$ & 110 & 32 & 94 & 232 & 301 & 91 & 52 & 106 & 103 & 50 & 25 & 64 & 1260 \\
\hline $\mathbf{2 0 1 0}$ & 64 & 25 & 52 & 167 & 213 & 78 & 49 & 115 & 90 & 53 & 31 & 74 & 1011 \\
\hline AVG & 108 & 36 & 96 & 244 & 288 & 89 & 52 & 143 & 140 & 66 & 34 & 97 & 1396 \\
\hline
\end{tabular}


Fig.1 Index map of Shipra river basin

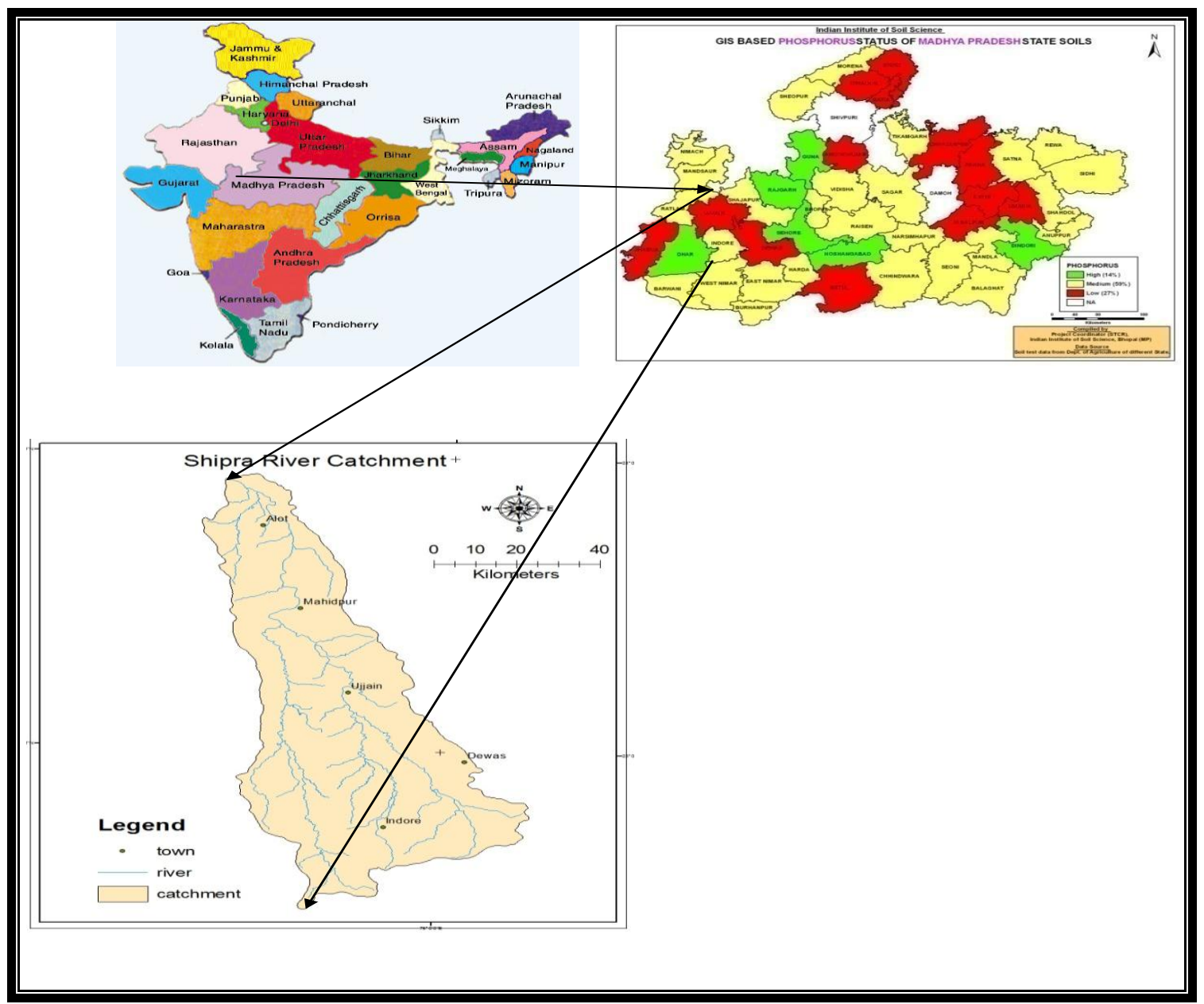

Fig.2 Annual variation of PET from 1990 to 2010

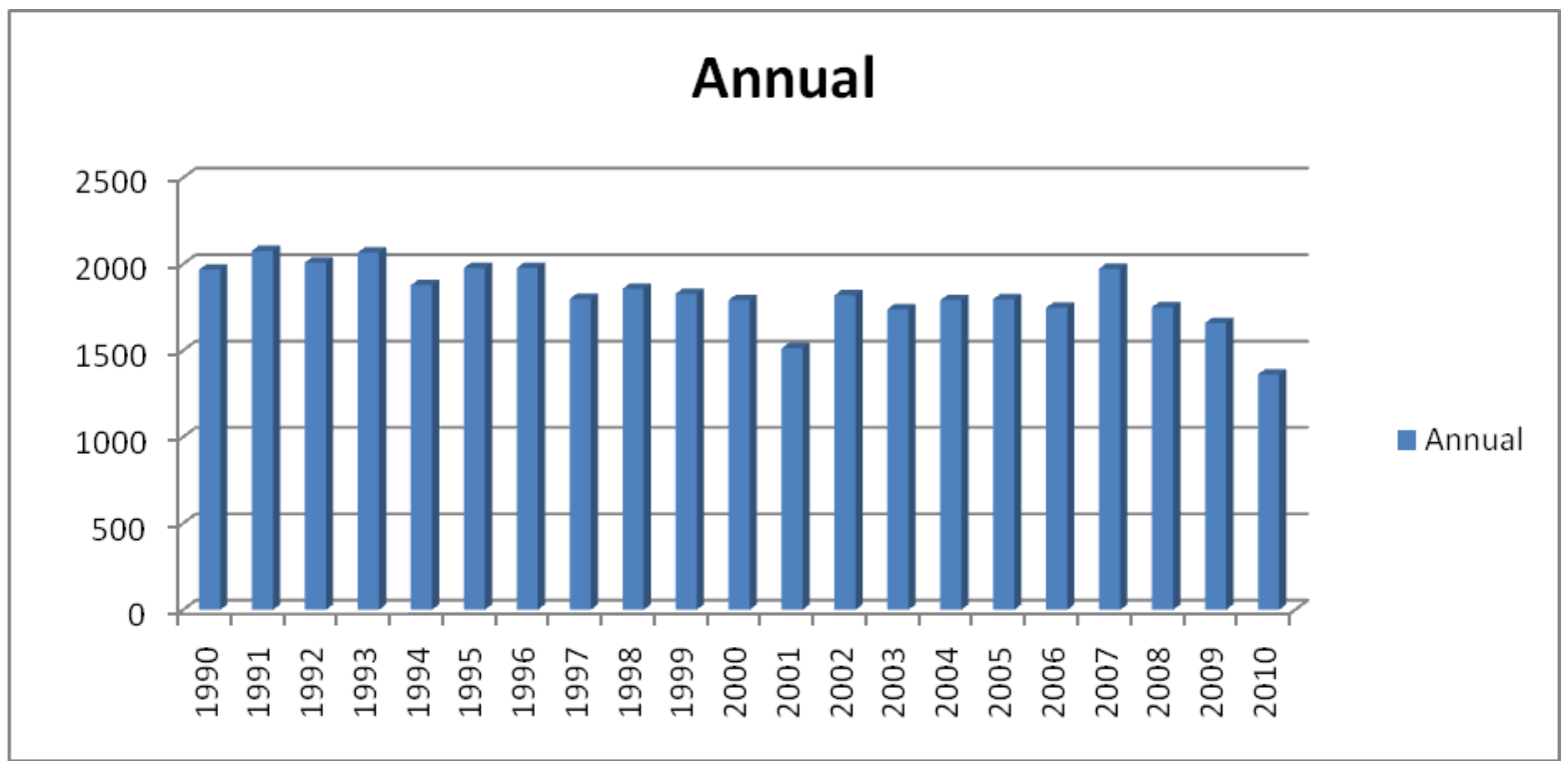


Fig.3 Annual variation of actual evapotranspiration from 1990 to 2010

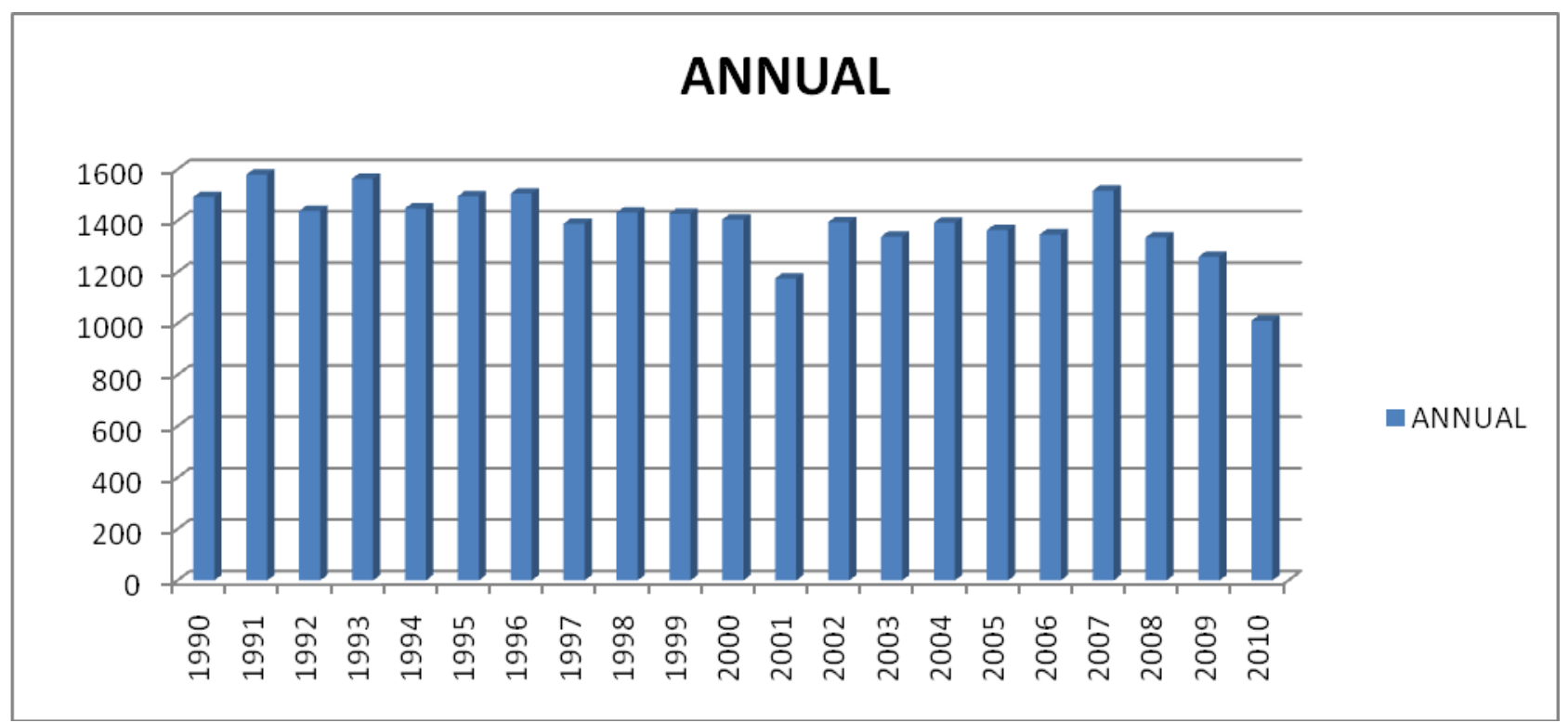

Therefore this can be concluded from the observation that maximum average ETo was in the month of May i.e., $259.7 \mathrm{~mm}$ due to highest temperature in this month and the minimum average ETo was in the month of December i.e., $90.5 \mathrm{~mm}$ due to minimum temperature in this month.

\section{Actual evapotranspiration}

The actual evapotranspiration was calculated using equation (2) and results are shown in Table 6 and 7. Annual Variation of Actual Evapotranspiration from 1990 to 2010 is also depicted in Figure 3. From the Table 7 and Figure 3 it is clearly depicted that maximum monthly actual evapotranspiration was estimated $381 \mathrm{~mm}$ in the month of May for the average period considered for the study and also for each years, the average highest annual actual ET value is $1580 \mathrm{~mm}$ due to high temperature during the year 1991.

Whereas minimum monthly ETo is estimated as $25.00 \mathrm{~mm}$ in the month of November due to winter months and low temperature. The average lowest annual actual ET value is 1011 $\mathrm{mm}$ in the year 2001. Thus it can easily be concluded that as the temperature increases the actual ET increases and as the temperature decreases the actual ET decreases. Therefore this can be concluded from the observation that maximum average actual ET was in the month of May i.e., $288 \mathrm{~mm}$ due to highest temperature in this month and the minimum average actual ET was in the month of November i.e., $34 \mathrm{~mm}$ due to minimum temperature in this month.

In this study CROPWAT 8.0 Model was used to determine the potential evapotranspiration and subsequently actual evapotranspiration using crop coefficient in the Shipra river basin for the time series 1990 to 2010. The maximum average ETo was in the month of May i.e., $259.7 \mathrm{~mm}$ due to highest temperature in this month and the minimum average ETo was in the month of December i.e., $90.5 \mathrm{~mm}$ due to minimum temperature in this month. It can be concluded from the observation that maximum average actual ET was in the month of May i.e., $288 \mathrm{~mm}$ due to highest temperature in this month and the minimum average actual ET was in the month of November i.e., $34 \mathrm{~mm}$ due to minimum temperature in this month. 


\section{References}

Allen et al., (1998) Crop evapotranspiration - guidelines for computing crop water requirements. FAO Irrigation and drainage paper 56. Food and Agriculture Organization, Rome.

Dariush et al., Estimation of Evaporation and Transpiration of Wheat Plant in Zaraghan Station Using CROPWAT Model, International journal of Advanced Biological and Biomedical Research Volume 2, Issue 4, 2014: 1362-1370.

Hashem et al., (2016), Performance Evaluation and Development of Daily Reference Evapotranspiration Model, Irrigat Drainage Sys Eng 2016.

Lindstrom et al., (1997). Development and test of the distributed HBV-96 hydrological model, Journal of Hydrology. Volume 201, Issues 1-4, 20 December 1997, Pages 272-288.

Tarate et al., (2017). Estimation of reference evapotranspiration for Parbhani district.
International Journal of Agricultural Engineering (10): 51-54.

Vivekanand Singh et al., (2006), ReferenceEvapotranspiration by Various Methods for Kashmir Valley, Journal of Indian Water Resources Society Vol. 26 No. 34, July-Oct., 2006.

$\mathrm{Xu}$ et al., (2000), Evaluation and generalization of radiation-based methods for calculating evaporation, Hydrological processes Volume 14, Issue 2: 339-349.

$\mathrm{Xu}$ et al., (2001), Evaluation and generalization of temperature-based methods for calculating evaporation, Hydrol. Process. 15: 305-319.

Zeleke et al., (2012). Evapotranspiration Estimation using Soil Water Balance, Weather and Crop Data. In A. Irmak (Ed.), Evapotranspiration: Remote Sensing and Modeling: 41-58.

Zhao et al., (2013). "Evapotranspiration estimation methods in hydrological models" J. Geogr. Sci. 2013, 23(2): 359-369.

\section{How to cite this article:}

Ayushi Trivedi, S.K. Pyasi and Galkate, R.V. 2018. Estimation of Evapotranspiration using CROPWAT 8.0 Model for Shipra River Basin in Madhya Pradesh, India. Int.J.Curr.Microbiol.App.Sci. 7(05): 1248-1259. doi: https://doi.org/10.20546/ijcmas.2018.705.151 